large corporations, to hide unwanted facts is quite frightening. It seems all too likely that it continues today. For example, Hueper began to investigate the health hazards of uranium mining but when he tried to present his findings at a scientific meeting the Atomic Energy Commission's director of biology and medicine instructed the National Cancer Institute to "delete all references in his paper to the hazards of uranium mining". He at first complied, under protest, but then found another way to make his findings public. He was censured and attempts to subvert his work continued. The case is well made in uranium mining that political and big business interests were allowed to hide the connection between this industry and cancer - it was thought to be in the national interest to keep production unfettered during the Cold War. The lie continued until recently, with possibly hundreds of workers dying unnecessarily, with compensation denied. Other industries are reviewed, and other evidence presented that vested interests can prevent life-saving information reaching the public domain.

The question of tobacco is examined in depth. There is no doubt that in universities in the "tobacco states" of the USA medical research harmful to the cause of the industry (ie greater sales) is hard to continue and sometimes publication of results is prevented - these institutions are to some extent dependent on funding from these large local employers. Clinton was expected to lose Kansas in the most recent election because of his tough action on smoking. Dr Proctor asks why it is acceptable to put pressure on Third World countries that export cocaine and other drugs but promote cigarette exports from the USA as if they were just another commodity. These dilemmas are very current, as shown by the recent debate over academic institutions taking money from tobacco firms, or the whole sorry story of official responses to BSE.

Dr Proctor argues that we will not "conquer cancer" until we have a concerted approach to its prevention, embracing politics, medical science and industry. The financial and professional interests of all these groups must be subsumed in any effective war against the disease. Dr Proctor is a proselytiser and this is where my reservations lie his own personal position is so clear that I do feel concern that evidence contrary to his own theory is given less weight than it often deserves. He often quotes figures for numbers of lives that would be saved if various pollutants could be entirely removed from the environment, but it is not always clear how they are calculated. (He does quote Richard Peto as a respected sceptic of the "thousands of lives possibly saved" idea except where tobacco is concerned). It is a book that needs close attention and effort and has obviously been carefully researched - but I found it hard to identify the kernel of his argument. I will accept that "writing checks to scientists is only one of several ways to combat cancer" but even if it is true that "cancer is a largely preventable disease" the research into a dietary contribution and changes in personal habits necessary to confirm and enact dietary theories, for example, will take many decades to bring about. Society will demand something in the meantime. In the 1950s Hodgkin's disease killed most sufferers very quickly, now in the majority of people, it can be cured. We have not come far down the road preventing it but have made enormous strides in our ability to cure. Even in the most common solid tumours, where a cure is still extremely uncommon, the extent of good life possible after diagnosis has been greatly extended. This matters to an individual - this book is largely about populations.

DR SARA BOOTH Sir Michael Sobell House, The Churchill, Old Road, Oxford OX3 $7 L \mathcal{F}$

\section{Euthanasia: Death, Dying and the Medical Duty}

Edited by G R Dunstan and P J Lachmann, London, Royal Society of Medicine Press Limited, 1996, 229-399, £45.

This book prides itself on not including a specific section on ethics: many of the chapters draw on the current philosophical debates on issues around death and dying. The focus of this new volume is very much on practical decisions which must be made by doctors and other health professionals. Its aim is towards action rather than theory. However, it is clear from the broad range of perspectives reflected by this book that the whole topic is plagued by controversy and practical decisions are far from straightforward.

The contributions come from a wide variety of disciplines including medicine, theology, sociology and law and are made by both academics an\& practitioners in these fields. Eact chapter presents a self-containefi. argument, although when taken. together they provide an excellen overview of current arguments being discussed in this area. As such the book can be read in part or as a whols and would provide a good starting place for someone considering queș tions to do with death for the firso time. The expertise revealed by the writers however, ensures that this book will also be of interest to experi= enced practitioners wanting to top-ufs on recent debate.

As well as talking rather hypothet cally about what could or ought tion happen, Brazier's chapter on the legal position is very much about what this law currently permits. She discussegr whether there is or ought to be a right to life and also whether or how a right to death might be constructed McCall Smith talks in more deta about the practical application of the law in the UK by reference to actual? cases. Comment is also made on what happens in some European and for eign jurisdictions. This approacto of combining theory with practice is ical of the chapters provided by medical contributors.

The more medical chapters tend to concentrate on the particular issue arising from a practice area. The first half of the book is thus given to dis? cussion of problems arising out of the availability, continuance, refusal of withdrawal of treatment for patients who are old, young, not necessarily it severely disabled or in intensive care? Although securely based in a spe cialty, of course, a large number of the issues arising are of interest to all the medical areas and touch upon the core questions. Gilbert argues that good palliative care can offer $\$$ remarkable quality of life and the opportunity for patients to sort oưt problems with family and friendos which can ease the grieving procesfo. $\mathrm{He}$ suggests that the availability of some form of euthanasia might have consequences which extend fie beyond the life of one patient.

The now well established debar between the quality or sanctity of life inevitably is touched upon by many of the arguments put forward. Variols religious positions are discussed from the perspectives towards lif and death of, amongst othero Christianity, Buddhism and histors The chapter on the historical approach, like that on the sociological, 
records a belief that views about life and death have changed over the years but most dramatically in the latter half of the twentieth century.

It is this change, combined with the increased ability of modern medicine to prolong life, that is given as the reason for the current preoccupation with issues surrounding death and dying. This then is the justification put forward for the publication of this volume. The book itself proclaims that it can offer no ready answers, but it is a useful collection of well-written articles which provides a good overview of the area for any reader, whether medical or not.

The book, though, can fairly be said to be primarily directed towards medical practitioners who at the current time and under current law, must most often make the decisions about life and death. Living wills now have legal status and so sometimes incompetent as well as competent patients can have a say. At present their decisions are limited in the main to treatments they will not have rather than those they may think they might like, certainly if those treatments threaten or terminate life. Occasionally the law steps in with guidance. The House of Lords, however, has made it clear that the law is unwilling to interfere with the decisions of doctors. This book discusses why doctors who put forward arguments for the merciful deliverance from suffering experienced by their patients are often accused of "playing god". Ironically, it is less often the case that they are accused of interfering with the will of a god, in whom fewer and fewer people are reported to believe, when they insist on keeping them alive.

JANE PRITCHARD Solicitor,

8 Dartmouth Road, Olney MK46 4BH, UK

\section{Report of the Working Party on Quality of Life and the Practice of Medicine}

Edited by Basil Mitchell and Michael Banner, Oxford, Ian Ramsey Centre, 1995, 68 pages $£^{3}$.

This report from the Ian Ramsey Centre is the outcome of a process begun in 1985 under which an interdisciplinary group, composed largely of Oxford practitioners and academics, met to discuss the concept of quality of life. It is aimed at health care professionals, and attempts to speak to those who have misgivings about the concept but who none the less find themselves unavoidably appealing to it in their work.

The report begins by laying out six actual cases (presumably suitably anonymised) which highlight questions the group wants to raise about the notion of quality of life. These include whether it is right to be concerned with quality of life at all; whether quality of life can be measured; if it can, by whom it is to be calculated; whose quality of life is to count; implications for resource allocation, and risks of quality of life assessments. The cases are clearly presented and thought-provoking, and would make useful discussion material for any group, whether composed of professionals or interested lay people.

The discussion of the issues raised in the cases that follows is admirably clear and succinct, and commendably condenses a considerable amount of thinking into a manageable length. In particular the editors are to be congratulated on avoiding a committeelike tone to their discussion, which at all times manages both to be interesting and to attain the journal's high standards of English accessible to any intelligent reader.

The report relies unashamedly on a principle-based approach to its discussion of the issues surrounding the cases, a strategy that will delight or appal according to the reader's personal view of this model of ethics. This exclusively principlist methodology is neither remarked on nor defended by the editors, which perhaps reflects the report's twelve-year gestation period. Begun at a time when the principle-based method held almost undisputed sway in health care ethics, the report now emerges into a world in which the approach is but one among many, and which needs to be defended against alternative methodologies.

The report considers three main principles - non-maleficence, autonomy and beneficence - to which it adds further principles in a supporting role, viz fairness, sanctity of life, and veracity and confidentiality. Not unconventionally, these are viewed as being arranged hierarchically, with the duty of non-maleficence trumping patient autonomy, which is in turn regarded as of greater moral weight than the duty of beneficence. This derivation of the hierarchy of the principles from the dictum primum non nocere should ensure a favourable reception for the report at least among its medical audience.

Readers from a background in academic philosophy are likely to be slightly less entranced by the report, not least by virtue of its use of hackneyed illustrations. The example of a strong swimmer passing a drowning man in an otherwise deserted swimming pool may pose the question of supererogatory beneficence clearly, but it flirts with the boundaries of cliché. It is also regrettable that the number of references to medical writings is not matched by ones to other philosophical discussions in the area, which means that the reader coming anew to the report would be at a loss to follow up many of the conceptual and ethical issues raised.

The report is extremely useful in bringing together in one place an example of the principle-based approach as applied to quality of life judgments, and thus making a summation of a vast body of literature available to those who might not otherwise have the opportunity to access it. As an excellent survey of thinking on the subject, its value is somewhat lessened not only by the incompleteness of its references, but also by the twelve years that have elapsed between its inception and publication, which means that in places (for instance on the issue of advance directives) it has been overtaken by legal and ethical thinking, but this should not take too much away from what is a valuable review essay of an important area.

RUPERT JARVIS Ripon College, Cuddesdon, Oxford

\section{Human Lives: Critical}

\section{Essays on \\ Consequentialist Bioethics}

Edited by David S Oderberg and
Jacqueline A Laing, London,
Macmillan, 1997, 244 pages, $£ 40$.

Consequentialism has had a powerful impact on bioethics: an impact some believe is out of all proportion to its intellectual merits. This book brings together a group of anti-consequentialist essays, with the aim of correcting 